\title{
PENGARUH LAMA PENYINARAN MENGGUNAKAN LAMPU LED TERHADAP PRODUKTIVITAS FODDER HANJELI (Coix lacryma-jobi L.) HIDROPONIK
}

(The Effect of Irradiation Length Using LED Lighting on Productivity of Hydroponic Job's Tears (Coix lacryma-jobi L.) Fodder)

\author{
Gina Salma Alghaniya ${ }^{1}$, Lizah Khairani ${ }^{2}$, Iin Susilawati ${ }^{2}$ \\ ${ }^{1}$ Mahasiswa Sarjana Program Studi Ilmu Peternakan Fakultas Peternakan Universitas Padjadjaran \\ ${ }^{2}$ Program Studi Ilmu Peternakan Fakultas Peternakan Universitas Padjadjaran \\ Jl.Raya Bandung - Sumedang KM.21, Jatinangor, Sumedang, Jawa Barat 45363 \\ Telp. (022) 7798241, Fax. (022) 7798212 \\ Penulis Koresponden : lizah@unpad.ac.id
}

Article Submitted: $14-10-2020$

Article Accepted: 24-12-2020

\begin{abstract}
A hydroponic indoor planting system needs manipulation of artificial lighting so that plants can produce optimal growth and production, one of them is by manipulating the length of irradiation using Light Emitting Diode (LED) lamps. This study aims to know the effect of irradiation length using LED lights on the productivity of Job's Tear's fodder in a hydroponic planting system. The research was conducted on January - February 2020 at Laboratory of Forage Crops, Faculty of Animal Husbandry, Padjadjaran University. Completely Randomized Design (CRD) was used in this experiment with three irradiation length treatments $(\mathrm{P} 1=12$ hours of irradiation; P2 $=16$ hours of irradiation; and P3 $=20$ hours of irradiation) with 6 replications. The data were analyzed by analysis of variance (ANOVA) and Duncan analysis. The results of statistical analysis showed that the length of irradiation using LED lights did not affect Job's Tear's fodder productivity of plant length, plant height, and dry matter production.
\end{abstract}

Keywords: hydroponics fodder, irradiation length, job's tears, $x$, Coix lacryma-jobi L., yield.

\section{PENDAHULUAN}

Hijauan berperan penting sebagai pakan utama untuk ternak ruminansia, sehingga ketersediaannya menjadi prioritas bagi peternak hewan ruminansia. Menurut Hasan (2012), hijauan yang baik berasal dari semua jenis tanaman hijau yang dapat dikonsumsi, tidak meracuni tubuh, dan zat gizinya dapat memenuhi kebutuhan hidup ternak. Hampir 90\% kebutuhan pokok ternak ruminansia bersumber dari hijauan yang kemudian digunakan untuk metabolisme tubuhnya sehingga dapat dikonversi menjadi produk peternakan, seperti daging dan susu.
Salah satu tanaman yang dapat dijadikan hijauan pakan adalah Hanjeli (Coix lacryma-jobi L.). Menurut Dnyandev (2012), daun Hanjeli merupakan hijauan yang berkualitas untuk ternak ruminansia sesuai dengan ketetapan dari ICAR (Indian Council of Agricultural Research) Standard tahun 1985. Ketetapan tersebut didasarkan pada kandungan nutrien daun Hanjeli yang meliputi BK 26,80\%; PK 11,60\%; TDN 54,87\%; SK 24,27\%; abu 8,90\%; Ca 0,57\% dan P $0,34 \%$. Hal itu menandakan bahwa hijauan Hanjeli memiliki nutrien yang tidak kalah potensial dengan hijauan asal tanaman serealia lainnya, seperti padi dan jagung. 
Banyaknya permasalahan dalam budi daya hijauan pakan pada sistem konvensional, seperti lahan sempit, masa pertumbuhan yang lama, dan faktor lingkungan lain yang tidak dapat dikontrol menjadi kendala dalam memproduksi hijauan pakan, sehingga diperlukan sistem tanam lain sebagai alternatif budi daya hijauan pakan. Salah satu sistem tanam yang dapat diaplikasikan yaitu teknologi hidroponik di dalam ruangan. Manajemen produktivitas tanaman dengan sistem hidroponik dinilai lebih efisien dibandingkan dengan penanaman konvensional. Menurut Polycarpou, dkk. (2005), sistem tanam hidroponik membuat fodder tumbuh lebih cepat dibandingkan tanaman pada sistem konvensional karena tidak ada penghalang mekanis pada akar sehingga unsur hara yang diserap oleh tanaman lebih efektif, serta hasilnya lebih bersih karena tidak ada peluang penyakit yang ditularkan melalui tanah.

Modifikasi radiasi matahari di dalam ruangan sebagai faktor lingkungan yang penting untuk sistem metabolisme tanaman sangat diperlukan. Salah satu komponen radiasi tersebut adalah intensitas cahaya. Intensitas cahaya memiliki pengaruh terhadap laju fotosintesis, laju transpirasi, pertumbuhan memanjang dan pertumbuhan menuju datangnya sinar, dan perkecambahan benih (Sugito, 2009). Intensitas cahaya merupakan banyaknya energi yang diterima oleh tanaman per satuan luas dan per satuan waktu ( $\mathrm{kal} / \mathrm{cm} 2 /$ hari), sehingga pengertian intensitas sudah termasuk di dalamnya lama penyinaran karena satuannya menggunakan hari. Menurut Leopold dan Kriedemann (1975), dari total intensitas cahaya matahari yang sampai ke permukaan bumi, tanaman hanya menggunakan $0,5-2 \%$ saja sebagai energi untuk produktivitasnya. Treshow (1970) menyatakan, bahwa Intensitas yang terlalu rendah akan menyebabkan hasil fotosintesis berkurang, sedangkan intensitas yang terlalu tinggi akan menyebabkan kerusakan pada klorofil.
Salah satu sumber penyinaran buatan di dalam ruangan yang dapat digunakan sebagai pengganti energi matahari adalah lampu Light Emitting Diode (LED) growth light. Lampu LED growth light memiliki spektrum yang dapat disesuaikan, seperti spektrum biru dan merah (Morrow, 2008). Menurut Hamim (2018), kedua warna tersebut efektif dalam produktivitas tanaman berkaitan dengan bagian klorofil tanaman yang aktif menyerap spektrum warna biru dan merah saat proses fotosintesis berlangsung. Sarkar dan Majumder (2013) menyatakan, bahwa konsumsi energi lampu LED rendah namun intensitasnya tinggi, serta dalam penggunaan yang lama tidak menimbulkan peningkatan suhu lingkungan, sehingga efisien untuk memaksimalkan pertumbuhan tanaman hidroponik di dalam ruangan.

Lama penyinaran merupakan durasi waktu per hari untuk tanaman menerima cahaya (Mattson, 2011). Produktivitas hijauan salah satunya ditentukan oleh lama penyinaran pada fase vegetatif. Menurut Sutoyo (2011), secara umum semakin lama tanaman mendapatkan penyinaran, maka proses fotosintesis akan berjalan semakin intensif, sehingga lama penyinaran berpengaruh terhadap fotosintat yang dihasilkan oleh suatu tanaman.

Respon tanaman Hanjeli terhadap lama penyinaran ditentukan oleh tipe fotosintesisnya. Nurmala (2009) menyatakan, bahwa Hanjeli merupakan tanaman C3 (short day plant) yang membutuhkan lama penyinaran selama 12 jam per harinya. Di sisi lain, Sutoyo (2011) menyatakan, bahwa umumnya semakin lama tanaman mendapatkan penyinaran, maka proses fotosintesis akan berjalan semakin intensif dan fotosintat yang terbentuk juga semakin banyak. Namun, selama ini belum ada penelitian mengenai pengaruh tambahan lama penyinaran menggunakan lampu LED growth light untuk tanaman Hanjeli pada sistem hidroponik terhadap produktivitasnya, sehingga penelitian ini 
bertujuan untuk mengetahui pengaruh lama penyinaran menggunakan lampu LED terhadap produktivitas fodder Hanjeli Hidroponik.

\section{METODOLOGI PENELITIAN}

Bahan yang digunakan dalam penelitian ini adalah benih Hanjeli jenis Pulut sebanyak 6.192 g untuk dibagi ke dalam 18 tray dengan masing-masing tray $(0,33 \mathrm{~m} \times 0,26 \mathrm{~m})$ berisi $344 \mathrm{~g}$, larutan $\mathrm{AB}$ Mix, air, dan fungisida. Alat yang digunakan berupa rak penelitian, tray, sprayer, 18 buah lampu LED growth light 7 W (1260 lux), TDS/EC meter, pH meter, termometer, ember, timbangan analitik, gelas ukur, penggaris, saringan, corong, gunting, amplop kertas, oven, silica gel, trash bag, kamera, dan tissue.

\section{Prosedur Penelitian \\ Seleksi Benih}

Benih direndam di dalam ember selama 24 jam untuk memisahkan benih yang baik dan yang tidak baik. Benih yang dipilih adalah benih yang tenggelam, sedangkan benih yang mengambang disisihkan karena berkualitas buruk. Selanjutnya, benih yang terseleksi direndam menggunakan fungisida selama 15 menit.

\section{Pematahan Dormansi Benih}

Benih Hanjeli yang telah direndam fungisida kemudian ditiriskan dan disemai pada tray yang telah diberi label sesuai dengan perlakuan, kemudian disusun dalam rak. Tray ditutup selama 3 hari dengan kertas koran yang telah dibasahi untuk menjaga kelembaban benih dan merangsang pematahan dormansi benih Hanjeli.

\section{Penanaman dengan Sistem Hidroponik}

Perkecambahan benih selama 3 hari dimulai setelah pematahan dormansi benih selesai, kemudian kertas koran dibuka. Selama 3 hari perkecambahan, penyemprotan dilakukan pada benih setiap 2-3 jam sekali untuk menjaga benih tetap lembab. Ketika benih selesai berkecambah, penyinaran dengan lampu LED dilakukan sesuai dengan perlakuan. Pada tahap ini, penyemprotan dilakukan dengan penambahan nutrisi $\mathrm{AB}$ mix sampai dengan umur panen.

\section{Pengukuran Produktivitas Tanaman}

Parameter pengukuran produktivitas terdiri atas panjang, tinggi, dan berat kering tanaman. Pengukuran panjang dan tinggi tanaman dilakukan setiap 3 hari sekali. Panjang tanaman diukur dengan kondisi tanaman yang ditegakkan, mulai dari pangkal sampai ujung daun tertinggi menggunakan penggaris dengan satuan sentimeter. Sementara itu, data tinggi tanaman diperoleh dengan cara mengukur tanaman menggunakan penggaris dari pangkal batang sampai bagian tanaman tertinggi dalam keadaan normal.

Parameter pengukuran bahan kering dilakukan saat dimulai fase pemanenan ketika umur tanaman mencapai 13 hari. Seluruh bagian tanaman dipanen untuk pengukuran akhir, yaitu penimbangan berat basah dan pengovenan untuk mengetahui produksi bahan kering yang dihasilkan. Pertama, dilakukan penimbangan berat basah total tanaman. Kedua, bagian tanaman antara akar dan batang dipisahkan, kemudian masing-masing ditimbang dan dimasukkan ke dalam amplop yang telah disediakan. Ketiga, seluruh sampel yang telah diperoleh dimasukkan ke dalam bagian oven secara terpisah antara sampel kelompok akar dan sampel kelompok batang. Bahan kering tanaman dapat diperoleh melalui pengeringan dengan oven pada suhu $105^{\circ} \mathrm{C}$ sampai beratnya konstan.

\section{Metode dan Analisis Data}

Rancangan yang digunakan pada penelitian ini adalah Rancangan Acak Lengkap (RAL). Terdapat 18 unit percobaan yang terdiri atas 3 perlakuan dan 6 ulangan. Perlakuan yang diberikan, terdiri dari $\mathrm{P}_{1}=$ Lama penyinaran menggunakan lampu LED selama 12 jam; $P_{2}=$ Lama penyinaran menggunakan lampu LED 
selama 16 jam; dan $\mathrm{P}_{3}=$ Lama penyinaran menggunakan lampu LED selama 20 jam. Data yang diperoleh kemudian diuji menggunakan Analisis Ragam (ANOVA) dan pengaruh perlakuan menggunakan uji lanjut Duncan.

\section{HASIL DAN PEMBAHASAN}

\section{Panjang Tanaman}

Berdasarkan uji statistik Analisis Ragam, seluruh perlakuan lama penyinaran menggunakan lampu LED tidak mempengaruhi panjang fodder Hanjeli hidroponik (Tabel 1).

Hal ini disebabkan oleh perlakuan lama penyinaran yang diberikan melebihi kebutuhan tanaman Hanjeli per harinya untuk melakukan proses fotosintesis, sehingga proses fotosintesis berlangsung tidak efisien terhadap kelebihan intesitas cahaya yang diberikan.

Tabel 1. Rataan Produktivitas Fodder Hanjeli Hidroponik pada Perlakuan Lama Penyinaran dengan Lampu LED

\begin{tabular}{|c|c|c|c|c|c|c|c|c|c|}
\hline \multirow{2}{*}{ Parameter } & \multirow{2}{*}{$\begin{array}{c}\text { Lama } \\
\text { Penyinaran } \\
\text { (jam) }\end{array}$} & \multicolumn{6}{|c|}{ Ulangan } & \multirow{2}{*}{$\begin{array}{c}\text { Rata- } \\
\text { rata }\end{array}$} & \multirow{2}{*}{ Signifikansi } \\
\hline & & 1 & 2 & 3 & 4 & 5 & 6 & & \\
\hline \multirow{3}{*}{$\begin{array}{l}\text { Panjang } \\
\text { Tanaman } \\
\quad(\mathrm{cm})\end{array}$} & 12 & 37,17 & 38,87 & 38,37 & 38,20 & 37,27 & 38,87 & 38,12 & \multirow{3}{*}{ ns } \\
\hline & 16 & 37,30 & 39,80 & 39,17 & 36,23 & 38,20 & 37,97 & 38,11 & \\
\hline & 20 & 37,37 & 38,43 & 37,47 & 38,73 & 37,23 & 37,10 & 37,72 & \\
\hline \multirow{3}{*}{$\begin{array}{l}\text { Tinggi } \\
\text { Tanaman } \\
(\mathrm{cm})\end{array}$} & 12 & 36,00 & 37,53 & 38,07 & 37,73 & 36,40 & 38,90 & 37,44 & \multirow{3}{*}{ ns } \\
\hline & 16 & 35,70 & 38,03 & 38,03 & 35,57 & 37,73 & 36,40 & 36,91 & \\
\hline & 20 & 36,17 & 37,67 & 37,30 & 37,83 & 36,30 & 35,77 & 36,84 & \\
\hline \multirow{3}{*}{$\begin{array}{c}\text { Bahan } \\
\text { Kering } \\
\text { Tanaman } \\
\left(\mathrm{g} / \mathrm{m}^{2}\right)\end{array}$} & 12 & 16,87 & 29,63 & 25,35 & 51,88 & 23,87 & 24,78 & 28,73 & \multirow{3}{*}{ ns } \\
\hline & 16 & 21,6 & 27,18 & 18,49 & 17,79 & 37,78 & 19,78 & 23,77 & \\
\hline & 20 & 22,43 & 19,31 & 18,81 & 16,63 & 34,91 & 16,18 & 21,38 & \\
\hline
\end{tabular}

Keterangan : $\mathrm{ns}=$ Nonsignifikan (tidak berbeda nyata) berdasarkan taraf uji 5\%

Hanjeli yang merupakan tanaman C3, lama penyinaran optimal yang seharusnya diberikan berkisar antara $10-12$ jam. Sesuai dengan hasil penelitian Ariffin (2008), bahwa tanaman kedelai (merupakan tanaman C3) memperlihatkan respon pertumbuhan dan hasil tanaman yang positif ketika diberi penyinaran selama $10-12$ jam, sedangkan penyinaran yang terlalu pendek atau terlalu panjang berdampak pada penurunan hasil tanaman kedelai. Sugito (2009) juga menyatakan, bahwa semakin meningkatnya intensitas cahaya, maka laju fotosintesis akan meningkat sampai batas optimum, namun peningkatan intensitas cahaya yang melebihi batas optimum tidak akan meningkatkan laju fotosintesis lagi. Hal tersebut menyebabkan fotosintat yang dihasilkan tidak bertambah banyak dengan bertambahnya lama penyinaran yang melebihi batas optimum, begitu pula dengan pertambahan panjang tanaman yang 
merupakan manifestasi dari fotosintat yang terbentuk.

\section{Tinggi Tanaman}

Berdasarkan hasil perhitungan statistik menggunakan Analisis Ragam, lama penyinaran menggunakan lampu LED tidak mempengaruhi tinggi fodder Hanjeli hidroponik (Tabel 1).

Data menunjukkan bahwa lama penyinaran dengan lampu LED tidak memiliki pengaruh terhadap tinggi fodder Hanjeli. Hal ini disebabkan oleh perlakuan lama penyinaran melebihi batas optimal penyinaran tanaman Hanjeli yang membuat proses fotosintesis tidak berlangsung secara efisien. Pertambahan tinggi tanaman sangat berkaitan dengan laju fotosintesis dan fotosintat yang dihasilkan. Salah satu faktor yang mempengaruhinya adalah jumlah intensitas cahaya yang sesuai. Menurut Hamim (2018), semakin banyak energi cahaya yang bisa diubah menjadi energi kimia, maka semakin besar reduksi $\mathrm{CO}_{2}$ menjadi gula, artinya fotosintat yang dihasilkan semakin tinggi. Namun, peningkatan intensitas cahaya tidak bersifat linier dengan peningkatan fotosintesis, melainkan bersifat parabola. Artinya, pada intensitas rendah adanya peningkatan cahaya sampai tingkat optimum akan meningkatkan laju fotosintesis, namun apabila intensitasnya melebihi batas optimum, maka pengaruhnya hanya sedikit terhadap peningkatan fotosintesis.

\section{Berat Kering Fodder Hanjeli}

Menurut Sitompul dan Guritno (1995), bahan kering adalah penumpukan fotosintat pada sel dan jaringan tanaman. Produksi tanaman merupakan hasil akhir dari seluruh proses fotosintesis, pengurangan fotosintat akibat respirasi dan translokasi bahan kering ke dalam hasil tanaman. Berikut data hasil penelitian lama penyinaran menggunakan lampu LED terhadap produksi bahan kering total fodder Hanjeli (Tabel1.)
Berdasarkan perhitungan statistik Analisis Ragam (ANOVA), dari ketiga data rataan perlakuan terhadap bahan kering fodder Hanjeli menunjukkan hasil yang tidak berbeda nyata. Sejalan dengan parameter pertumbuhan tinggi dan panjang tanaman sebelumnya, lama penyinaran menggunakan lampu LED tidak mempengaruhi berat kering fodder. Hal ini sesuai dengan pernyataan Jumin (1994), bahwa peningkatan produksi tanaman berbanding lurus dengan peningkatan pertumbuhan relatif dan hasil bersih fotosintesis, sebab biomassa tanaman yang telah dikeringkan merupakan penumpukkan bahan kering di dalam tanaman selama masa pertumbuhan.

Seluruh perlakuan lama penyinaran, yaitu 12 jam, 16 jam, dan 20 jam menggunakan lampu LED telah melebihi batas kritis waktu penyinaran tanaman Hanjeli yang juga menyebabkan kejenuhan jumlah intensitas cahaya yang diterima tanaman, kemudian membuat efisiensi fotosintesis berlangsung rendah. Hal ini sesuai dengan pernyataaan Sugito (2009), bahwa pada daun bagian atas sering terjadi keadaan jenuh yang akibat kelebihan jumlah intensitas cahaya karena melebihi batas optimum yang dapat diterima oleh daun untuk proses fotosintesis. Pada umumnya, intensitas cahaya yang tinggi tersebut membuat proses fotosintesis pada daun tidak efisien dan daun mengalami kejenuhan penerimaan energi cahaya, sehingga tidak ada lagi pembentukan fotosintat yang mempengaruhi jumlah produksi bahan kering fodder.

\section{KESIMPULAN}

Lama penyinaran menggunakan
lampu LED tidak mempengaruhi
produktivitas fodder Hanjeli (Coix lacryma-
jobi L.), baik pada parameter tinggi,
panjang, maupun berat kering fodder pada
sistem hidroponik.




\section{DAFTAR PUSTAKA}

Ariffin. 2008. Respons Tanaman Kedelai terhadap Lama Penyinaran. Jurnal Agrivita. 30(1): 61-66.

Dnyandev, L. P. 2012. Nutritional Evaluation of Kashat (Coix lacryma Jobi-L.) Grass in Goats. Disertasi Departemen Agrikultur Dr. Balasaheb Sawant Konkan Krishi Vidyapeeth. Dapoli. Hal. 43 - 59.

Hasan, S. 2012. Hijauan Pakan Tropik. IPB Press. Bogor. Hal. 1-3.

Hamim. 2018. Fisiologi Tumbuhan 1 (Air, Energi, dan Metabolisme Karbon). IPB Press. Bogor.

Jumin, H. B. 1994. Dasar-dasar Agronomi. Edisi Pertama, Cetakan Ketiga. Raja Grafindo Persada. Jakarta.

Leopold, A. C dan P. E. Kriedemann. 1975. Plant Growth and Development. Second Edition. Tata Mc, Grow. Hill Publishing Campany Ltd. New Delhi. Hal. 545.

Mattson, N. 2011 . Greenhouse Lighting. Cornell University. New York.

Morrow, R. C. 2008. LED Lighting in Horticulture. J. Hort. Sci. 48 (7): 1947-1950.

Nurmala, T., Qosim, W. A., dan Achyar, T. S., 2009. Eksplorasi, Identifikasi dan Analisis Keragaman Plasma Nuftah Tanaman Hanjeli (Coix lacryma-Jobi L.) sebagai Sumber Bahan Pangan Berlemak di Jawa Barat. Laporan Penelitian Strategis UNPAD. Sumedang.
Polycarpou, P., Neokleous, D., Chimonidou, D. and Papadopoulos, I. 2005. A Closed System for Soil Less Culture Adapted to The Cyprus Conditions. In: Hamdy A. (ed), F. El Gamal, A.N. Lamaddalen, C. Bogliotti, and R. Guelloubi. Non-conventional water use. Hal. 237- 241.

Sarkar, A dan Majumder, M. 2013. Opportunities and Challenges in Sustainability of Vertical EcoFarming: A Review. J. of Advanced Agricultural Technologies. 2 (2): 98 - 105.

Sitompul, M. S. dan B. Guritno. 1995. Analisis Pertumbuhan Tanaman. Gadjah Mada University Press. Yogyakarta.

Sugito, Y. 2009. Ekologi Tanaman (Pengaruh Faktor Lingkungan terhadap Pertumbuhan Tanaman dan Beberapa Aspeknya). Brawijaya University Press. Malang.

Sutoyo. 2011. Fotoperiodisme dan Pembungaan. Buana Sains. Vol. 11. 137-144.

Treshow, M. 1970. Environtment and Plant Response. Mc Graw Hill Company, New York. 